\title{
Towards an Indecent Queer Activism: Interrogating the Relationship between Christianity, Civilised Whiteness and Queer Politics in South Africa
}

\section{Megan Robertson \\ ORCID iD: https://orcid.org/0000-0002-2861-152X}

\begin{abstract}
The history of queer politics in South Africa has been framed by tensions between the struggle for gay rights and black freedoms. Christian and cultural beliefs and discourses underlie these past tensions and continue to inform black resistance to the plight of gay black men, and white gay activists' ambivalence to black freedoms. These same religious influences, along with politics of power, largely exclude women and trans-persons from featuring in either side of the debate. This paper argues that contemporary gay politics has largely developed as a response to the policing of white gay men and in many ways has not developed into an intersectional queer activism. This paper adds nuance to existing critiques of gay politics of contemporary South Africa by analysing the construction of 'civilised' white sexuality within the political discourse of South Africa. In addition, this article draws on a queer and decolonial analytic to review literature which has explored the varied agencies of religious, African and trans queer people. In doing so, this paper argues for the development of an 'indecent' activism that challenges dominant narratives that frame queer activism in South Africa today.
\end{abstract}

Keywords: queer, agency, Christianity, whiteness, activism, indecent, South Africa 


\section{Introduction}

Following his acquittal and release from prison on charges of treason against the apartheid government because of his association with the United Democratic Front (UDF) ${ }^{1}$, prominent struggle icon, Simon Nkoli, along with Beverley Ditsie and Linda Ngcobo, co-founded the Gay and Lesbian Organisation of Witwatersrand (GLOW) (Hoad et al. 2005: 30). GLOW was formed partly in response to the supposedly 'apolitical' stance of the largely white gay rights organisation, Gay Association of South Africa (GASA), which failed to support Nkoli during his imprisonment.

GLOW went on to organise South Africa's first Pride march in 1990 in Johannesburg. Nkoli's speech at this event highlighted the intersectionality of race and sexuality,

This is what I say to my comrades in the struggle who ask me why I waste time fighting for moffies [derogatory term for gay men], and this is what I say to white gay men, or women, who ask me why I spend so much time talking about apartheid when I should be fighting for gay rights: I am black and I am gay, I cannot separate the two parts of me into secondary and primary struggles, they will be all one struggle (Ditsie \& Newman 2002).

The attention Nkoli and GLOW brought to the indivisibility of black rights and other freedoms was significant. The establishment and work of GLOW is, in some ways, emblematic of the history of queer politics in South Africa which has been framed by tensions between the struggle for gay rights and black freedoms ${ }^{2}$.

In 1996, Nkoli's call for gay rights to be represented along with the black freedom promised by a democratic South Africa was achieved, at least

${ }^{1}$ Simon Nkoli was on trial with 21 others in what became known as The Delmas Treason Trial. According to the record curated by Gala (previously the Gay and Lesbian Archives), 'The prosecution was trying to prove that the UDF intended to overthrow the state by violence, independently or in conspiracy with the banned African National Congress. These were serious charges, which potentially carried the death penalty' (Gala 2019).

${ }^{2}$ For a more comprehensive history of this see Hoad et al. (2005) and Gevisser (1995). 
judicially, when South Africa became the first country in the world to enshrine protection for its citizens on the basis of sexual orientation in its constitution (Isaack 2003). In doing so, the country has become a symbol of queer ${ }^{3}$ rights and freedoms in Africa. However, there are notable limitations to the freedoms brought about for queer people in a post-apartheid South Africa. Queer people, especially queer women, trans persons, queers of colour, and the economically disadvantaged bear the brunt of negative and often violent consequences of being queer in South Africa. In recognising this, scholars have become increasingly critical of past and current dominant gay/queer rights discourses and activist work. In an interview with Nadia Davids, Zethu Matebeni (Davids \& Matebeni 2017: 162) makes a distinction between gay rights activism and queer activism. Matebeni characterises gay rights activism as that which represents the interests of a narrow privileged few, namely white, cis, gay men, while a queer activism critically incorporates multiple experiences and oppressions in relation to race, gender, sexuality and class. For Matebeni, gay rights activism is most evident in contemporary Pride politics, while the activism of Nkoli more readily represents an intersectional ideal. She elaborates,

There is a huge departure from the first Pride...from Simon [Nkoli] to a Pride that you go and see now in Johannesburg, in Sandton... In Cape Town it's in GreenPoint. And already that tells you something. Where is that working-class history? Where is that politic? What happened to the fight for rights? (Davids \& Matebeni 2017: 163)

This is not to say, however, that there were not notable limitations to the intersectionality GLOW and Nkoli represented at the time. Beverley Ditsie in her film, Simon and I (Ditsie \& Newman 2002), for example illustrates that the unique experiences of lesbian women (and I would add, trans persons) were often disregarded in GLOW's agenda. The point that Matebeni makes, however, is important as it questions what queer activism looks like in

\footnotetext{
${ }^{3}$ Noting the politics, particularly in Africa, around the use of the term 'queer', in this paper I use it not only as a theoretical lens to interrogate politics but also in reference to non-normative sexualities and gender non-conforming people. By using it as an identity marker, I am able recognise the fluidity of identities and to encompass a range of gendered and sexuality performances.
} 
contemporary South Africa. In her work, Matebeni (2017: 26) has called for 'reimagining the category queer not just as sexual or gender identity, but also as a form of destabilizing notions of belonging attached to the racist and heteronormative neo-colonial project'. Scholars have argued that this process involves theorising the lived experiences of various queer people in South Africa to expanding and nuancing conceptualisations of queer resistance, activism and agency in Africa and South Africa (cf. Francis \& Reygan 2016; Matebeni et al. 2018). Yet, while this has led to important critiques of queer activism in contemporary South Africa, the intersections of religion as identity and its political influence on queer rights discourse remain under examined.

Religious and cultural discourses continue to produce and support systems and actions which marginalise many queer South Africans (Vincent \& Howell 2014). This is evident from the results of a survey of attitudes towards homosexuality and gender non-conformity in South Africa by the Human Sciences Research Council (HSRC) released in 2015. The report indicates that 450000 South Africans had physically harmed women who dressed and behaved like men in public and 240000 had physically harmed men who dressed and behaved like women in the twelve months prior to the data collection. Further, approximately 700000 South Africans verbally abused (shouted at or teased) gender non-conforming people (HSRC \& The Other Foundation 2015).

These harmful expressions have been linked through statistics and research to widely held conservative moral beliefs about individual sexual activity and gender roles which are connected to underlying religious beliefs (HSRC \& The Other Foundation 2015; Vincent \& Howell 2014). In the same survey, for example, just over three quarters $(76 \%)$ of the respondents agreed with the statement, 'God's laws about abortion, pornography and marriage must be strictly followed before it is too late', with one in three people voicing 'very strong' support. A very similar pattern of responses was recorded for the statement, 'women should obey their husbands', demonstrating the continuing strength of patriarchal norms and values in South Africa (HSRC \& The Other Foundation 2015).

In this paper I explore Christianity's past and current impact on queer politics in South Africa. I draw on the work of historians to demonstrate how the privileging of Christianity and discourses of 'civility' and morality serve as a marker through which queer sexuality is understood. I argue that, in order 
to challenge colonial systems and ideologies, contemporary queer activism must consider the lived experiences of 'unusual' queer people - for those whom normative queer identity and activism is not shaped around. In this paper I bring a commentary on 'civilised' white gay politics into conversation with critiques offered by decolonial queer feminist religious scholars in relation to Euro-American forms of queer activism. Using a queer decolonial analytic and drawing on Marcella Althaus-Reid's (2000) concept of the 'indecent', I suggest the move toward scholarship and social activism that acknowledges the intersectional nature of oppression as well as a multiplicity of agencies and imagines a broader collective response. I propose that an indecent queer activism, one that challenges the decency of gay rights discourse, may inform what queer activism looks like in contemporary South Africa.

\section{Christianity, 'Civilised' Whiteness and the Bogeyman of Homosexuality}

Apartheid identity policing was not limited to physical attributes of race or even gender (cf. Croucher 2002; Martens 2007). Policing very often extended to behaviour where performances of Christian morality and civility served as the ideal benchmark to which to aspire. Jeremy Martens (2007: 235) argues, 'the fusion of discourses of biological race with those of civilisation demanded that whites conduct themselves in a 'civilised' manner'. This ideal was most visibly achieved by the upper/middle class white Christian males while its biggest threat came from, what Ann Stoler (1995: 96) terms, 'internal enemies'. Key among these enemies were poor white people who disrupted the racial connection to bourgeois values (Martens 2007: 224) and gay white men who subverted the connection between race and sexual restraint and gender order. Whiteness was defined in both moral and racial terms, and those white people who lived immorally obstructed the equation of race with civilisation and blurred the racial boundaries on which White supremacy was predicated (Martens 2007). It is this threat to the ideology of civilisation that was largely of concern to the apartheid government.

In 1967 Peet Pelser, the South African Minister of Justice at the time, gave a speech in parliament during a debate about including amendments to the 1927 Immorality Act, which criminalised miscegenation and declared it the ultimate offence to this notion of civility and morality (Martens 2007: 225). In arguing for the criminalisation of homosexuality he said, 
History has given us a clear warning and we should not allow ourselves to be deceived into thinking that we may casually dispose of this viper in our midst by regarding it as innocent fun. It is a proven fact that sooner or later homosexual instincts [will] make their effects felt on a community if they are permitted to run riot [...] Therefore we should be on the alert and do what there is to do lest we be saddled later with a problem which will be the utter ruin of our spiritual and moral fibre (cited in Retief 1995: 99).

In his speech, Pelser invokes religious imagery relating to the serpentine instigator of 'original sin' to construct the 'bogeym[a]n' of homosexuality (Gevisser 1995: 31). In this way, homosexuality is positioned as a threat to the ordained gender order and the Afrikaner nation - a volksgevaar (danger to the nation) (Du Pisani 2012: 192). Kobus Du Pisani (2012: 182) notes that this was a key policing tool of apartheid where moral panic was manufactured through the mobilisation of religious, media and legislative resources. Traditional 'civilised' Christian theologies of sex were used to exclude discourses that suggested the existence and condoning of fluidity or nonprocreative sex. According to Masiiwa Gunda (2017: 19), 'this was a Christianity that even went as far as deciding which sexual positions were godly or ungodly'. Nicky Falkof (2019) illustrates that gay white men were literally demonised and linked to the apparent spread of Satanism in late apartheid South Africa.

The bogeyman of homosexuality was especially threatening to Whiteness and, because of this, much of the early policing of homosexuality was directed at white internal enemies. Scholars have demonstrated that legislation and discourse gave scant attention to lesbian women or black men who have sex with men while trans persons were, and continue to be, all but erased from the narrative (Retief 1995; Gevisser 1995: 18; Ratele 2009; Du Pisani 2012: 189; Carolin 2017). In fact, even when lesbian women were discussed by apartheid lawmakers, the central concern was still for white masculinity. Glen Retief (1995: 103) states, 'the MPs [members of parliament] were rather worried about the sizes, shapes and attributes of the different kinds of 'dilders' [dildos] used by lesbians - with one MP enquiring whether 'this instrument [is] of normal or abnormal size',

The moral panic around white men's homosexuality is significant as it forms the backdrop around which gay politics in South Africa developed. 
Although emerging as a response to apartheid's attempt to criminalise and police homosexuality in some sense, the struggle for gay rights has been equally a product of apartheid Christian ideologies of race, gender and sexuality.

\section{Civilised Gay Politics in Post-apartheid South Africa}

The nature of gay politics in post-apartheid South Africa largely emerged as a reaction to apartheid policing. Therefore, as I elaborate below, Christian ideologies and the emphasis on white masculinity continue to inform the very nature and form that resistance has taken. While GLOW and the black queer men and women they represented may have been instrumental in placing queer sexuality on the constitutional agenda of post-apartheid South Africa, the decriminalisation of homosexuality and the expansion of the queer freedoms have largely remained framed as white issues in post-apartheid South Africa.

The Whiteness that pervades gay rights discourses in contemporary South Africa is partly as a result of the continued colonial discourse that equates Blackness with religious and cultural conservativism. Ironically, this discourse has often been framed in opposition to coloniality. Neville Hoad (1999: 566) has identified common queer discourses in post-apartheid South Africa which suggest three ${ }^{4}$ distinctive framings, namely, Corruption, Preservation and Universalist. The Corruption frame constructs homosexuality as colonialist and 'unAfrican'. Conservative religious and traditional leaders often rely on this framing to make arguments against homosexuality (Nyanzi 2013). However, the irony is that these arguments rely heavily on notions of colonialist and apartheid Christian morality to construct an idea of 'civilised' Africanness (Thoreson 2008: 688). In this framing, performances of a dignified, respectable, Christian, 'Thabo Mbeki Africanness' becomes recognised as the authentic expression of African. In many ways, however, this understanding of Africanness is simply civilised Whiteness clothed in black and the bogeyman of homosexuality is now constructed around the threat of colonial white queer sexualities. Historically this taken-for-granted and inherently contradictory understanding of civilised

\footnotetext{
${ }^{4}$ While Hoad suggested two framing's, Ryan Thoreson (2008: 689) made three distinctions based on Hoad's work.
} 
Africanness has had negative consequences on HIV/AIDS activism and queer liberation in South Africa. Possibilities of male-male sexual transmission of HIV infection were considered so rare that they were not seriously considered as a space of intervention. Marc Epprecht (2008) demonstrates that even important scholarly texts aimed at healthcare professionals sometimes went as far as to limit the representation of HIV transmission in Africa to three heteronormative modes, namely heterosexual intercourse, intravenous injection, and mother-to-child transmission.

The Preservation and Universalist discourses have in some ways developed in opposition to the Corruption argument. The Preservation discourse criticises colonial taboos and celebrates sexual diversity as inherently African, while the Universalist frame regards sexual orientation as a human right that is not intrinsic to any particular time or place (Thoreson 2008: 688). Queer activists as well as those opposing queer rights have sometimes invoked an uncritical use of either of these discourses to make arguments for or against homosexuality (Thoreson 2008: 689). However, there are also limits to these discourses. The danger of the Preservation discourse is that it tends to produce romanticised notions of an equal, democratic pre-colonial Africa and thereby wishes away patriarchy and heteronormativity in 'authentic' African culture. On the other hand, the Universalist discourse often frames Africa in relation to other parts of the world where queer sexualities are seemingly more accepted. Thus, the queerphobic tendencies that are evident in Africa become framed as uncivilised and archaic in their reliance on biblical scripture and cultural tradition.

Xavier Livermon (2012) makes an astute commentary on the paradox that exists in discourses of queer politics which either frames homosexuality as a threat to Africanness or situates Africa as constitutionally progressive and queer-friendly. He argues that the ability of homosexuality in the South African context to be representative of both 'democratic modernity' and a 'threat' rests on the racialisation of the queer body as white and the sexualisation of the black body as straight (Livermon 2012: 301). Thus, he argues,

The white queer body is emblematic of human rights protections used to position South Africa as a progressive queer-friendly tourist destination (for white queer tourists), while the black queer body 
remains the threat to African culture and tradition. The policing of queer bodies in post-apartheid South Africa falls disproportionately on black queer bodies (Livermon 2012: 301).

However, while the policing has shifted from white male bodies during apartheid to black queer bodies in post-apartheid South Africa, the focus of politics and activism has not.

Ryan Thoreson (2008: 682) positions post-apartheid South Africa as having delivered internationally unprecedented 'judicial success'. He attributes this success primarily to litigation, with parliamentary allies providing secondary support. Thoreson characterises gay rights activism in post-apartheid South Africa as, 'quite well-organised, well-resourced, and able to tap into the expertise of gay and lesbian people across the society' (Thoreson 2008: 685). He argues that, 'from the earliest days of the postapartheid era, the movement recognised that coherent, principled rhetoric rather than the support of the masses was the key to success' (Thoreson 2008: 685). Thoreson (2008: 685) places this in relation to the black women's liberation movement, attributing their relative lack of success to their deep linkages with the African National Congress (ANC) government and their attempts at mass mobilisation. Drawing on Charles Tilly, he further argues that "movements regularly seek favour by displaying "sobriety, propriety of dress, incorporation of priests and other dignitaries, endorsement of moral authorities, [or] evidence of previous undeserved suffering" (cited in Thoreson 2008: 687). Illustrative of the moral clout attached to gay rights in South Africa, is the public support of Archbishop Desmond Tutu who has lent a moral uprightness and civility to queer rights movements in recent years.

While Thoreson may accurately be accounting for the strengths and successes of gay political activism, it is important for scholars to continue to critique the ideologies which lends themselves to this success. In fact, it is the very codes which govern understandings of civility that make for 'successful' activism. 'Civilised' gay politics sustains notions that only educated middleand upper-class gay men meet appropriate standards of citizenship and thus their rights become normative. This logic then also maintains that to be black and African is to be culturally, traditionally and conservatively Christian - a social location which, at least according to Euro-American gay politics, has no place in achieving gay rights. Finally, it argues that if activism is to be performed it should be done in a 'civilised' manner in the courts and not 
through mass action nor in everyday ways in communities and institutions. This has led to a number of limitations on gay rights activism in South Africa.

\section{The Limitations of Civilised Gay Politics}

While many legal and political fights for freedom and inclusion have been won through civilised gay politics, freedoms and inclusion which stretch beyond the legal and political and into the social and cultural spheres, have been less successful. As Thoreson elaborates (2008: 695), 'the public may not be willing to tolerate gay and lesbian individuals in their community, but appear grudgingly to tolerate the gay rights rulings of the Constitutional Court as a necessary (if undesirable) by-product of democratisation'. I argue that the civil nature of gay rights activism has been unsuccessful in three key respects. First, the violence experienced by black lesbian women in South Africa remains marginal to the rights of gay men. Second, victories in the courts have still centred on heteronormative ideals of family. Third, ideologies of 'civility' have dismissed the varied ways in which transformation can be brought about through diverse action.

First, neglected in narratives of South Africa as an African queer utopia are the continued effects of the pervasive structural and social inequalities, shaped by the country's history of apartheid racial segregation and violence. Natalie Oswin (2007: 666) argues that the National Coalition for Gay and Lesbian Equality (NCGLE), which constructed itself as the umbrella body for gay and lesbian interests around the country, 'opted to pursue a politics of strategic essentialism that ignored the ways in which class, race, and gender issues are inevitably intertwined with sexuality'. Thus, gay politics in post-apartheid South Africa have been framed around the needs of upper/middle class queer people with the primary focus remaining on legal and lobbying activities. Yet, as Livermon (2012: 300) argues, freedom suggests not merely the existence of a diversity of bodies but involves the freedom to construct 'liveable lives', as described by Judith Butler (2004), through the 'public naming and performance of gender and sexuality dissidence with the understanding that such public disclosures will not result in the curtailment of or loss of life'. Research focusing on the experiences of black lesbian women in South Africa shows that while homophobic violence is generally high, black lesbians are particularly vulnerable to violence, 
specifically murder and 'corrective rape' 5 because of the potential their sexual identity holds to destabilise the patriarchal gender order and its heteronormative practices (Lake 2014). In addition, Whiteness and homonormativity continue to exclude black lesbian women from economic, cultural and social power (Davids \& Matebeni 2017). Beverley Ditsie's (Ditsie \& Newman 2002) critique of GLOW during apartheid for failing to adequately recognise black lesbian experiences as part of their activist agenda, remains an oversight of gay political activism in post-apartheid South Africa.

Second, legal victories won around marriage and adoption have been critiqued for not fulfilling the queer imaginary. The debate in international queer marriage politics has centred around the broadening of legal marriage rights to include same-sex marriages and, some might argue, around a legally broader definition of family (Harvey 2015: 103). Jennifer Harvey (2015) has characterised this debate into two central arguments, namely assimilation and subversion. On the one hand, theorists and activists adopting an assimilation stance argue that issues of marriage equality fail to disrupt or trouble the powerful history of marriage as a heteropatriarchal institution (Duggan 2003; Queen 2008). In addition, marriage equality activism is seen as a single-issue and thus obscures the numerous social injustices experienced by a plurality of queer lives (Weber 2015: 1148). On the other side of the debate of queer marriage politics, those who ascribe to the subversion argument suggest that there is in fact nothing more subversive than same-sex marriage as it challenges the very notions of gender complementarity and gender roles in family contexts and thus subverts the idea of heteronormative ideals of marriage (cf. Sistig 2011; Sistig \& Nadar 2011).

Harvey (2015: 109), however, rejects views which are situated firmly on either side of the assimilationist-subversion debate. She argues rather than being a helpful framework for understanding marriage politics, it ignores the varied motivations, ethical dilemmas and realities around which people construct a multiplicity of marriage and family forms. Harvey (2015: 110) suggests moving the debate in scholarship away from exploring whether queer families and specifically same-sex marriage are either assimilationist or subversive. Rather, she argues, research should focus on exploring the various familial and kinship realities of queer lives and how these are situated within

${ }^{5}$ A contested term which is used to refer to the raping of lesbian women to 'correct' them to heterosexuality (Lake 2014). 
institutional and discursive contexts. Therefore, I do not dismiss the importance that achieving the recognition of same-sex marriage has had for many queer people in South Africa. However, it has also resulted, according to Oswin (2007), in activism apathy. Contemporary activist movements continue to neglect to account for the experiences of variously constituted queer families and kinships that have the potential to disrupt normative powers of race, class, gender and sexual orientation. Further, even recent decolonial activist movements such as \#RhodesMustFall have been critiqued by a trans student activist group, the Trans Collective, for failing to recognise and adequately represent trans rights and experiences in their agenda (cf. Shefer 2019).

Third, because notions of civility have legitimised particular versions of activism over others, more weight is given to measures of activism which are 'logical' and make use of systems which require resources available to only a privileged few. A more nuanced look at the ways in which transformation can and has taken place is neglected. A hegemony of activism is constructed which centres around the actions of men in formal structures. Protest, mass action, and the recognition and publicization of bodies and sex are constructed as disruptive to the agenda (Shefer 2019). The need to maintain civility has limited the way visible actions such as Pride have evolved to exclude poor, black and transgendered people. Meanwhile, queer silence is framed homogenously as the result of either fear or complicit apathy. Single-issue agendas, the maintenance of heteronormativity and a rhetoric of civility lends itself to a limited rights discourse and activism which tends to perpetuate the very systems it seeks to dismantle. While the aims of queer activism and queer theory have been to gain recognition and create liveable lives for queer people, as Oswin (2007: 656) argues, 'the way in which prominent gay and lesbian organizations have gone about gaining this legitimacy in recent years has turned out to not quite be what queer theorists had in mind'.

\section{Towards an Indecent Queer Politics}

Queer political discourse and activism is not necessarily queer when the spaces in which it takes place and the limits of its content perpetuates the systems of power it seeks to disrupt. I want to suggest that the politics which queer theorists had in mind would challenge the fabric, textures and systems 
that continue to favour those who are white and male, to silence women, to exclude those who are black and poor, and celebrate heteronormativity. In order to stretch the limitations of the civilised gay politics and the resulting activism which has been cluttered with notions of what it means to be 'civilised', I offer the idea of moving towards an indecent queer politics.

I borrow the concept 'indecent' from Marcella Althaus-Reid's (1999: 39) proposal of an indecent theology which she defines as, '...a positive theology that aims to uncover, unmask and unclothe that false hermeneutics which considers itself as 'decent' and as such, proper and befitting for women especially in sexual matters'. In this paper, the false hermeneutics is that of civilised activism marked as befitting for decent, queer people. Gerald West (2018) states that an indecent lens brings together queer theory's recognition of the sexual with liberation theology's focus on the political and economic. An indecent lens could therefore be understood as a queer decolonial analytic. Althaus-Reid's (1999: 39) call to subvert and transgress notions of decency is based on the inclusion of the experiences and lives of women and 'the poor'. In applying this lens to queer activism, I suggest, we may uncover activism which disrupts and operates against colonial systems and ideologies. Informed by postcolonial and queer theory Althaus-Reid asks scholars to theorise the experiences of 'unusual Christian believers', in other words those for whom normative Christian theologies are not shaped around. I want to suggest that the development of an indecent activism would require scholars to critically theorise the various modalities of agency that 'unusual' queers engage in. Below I briefly look at the activisms exposed in the lives of three unusual queers, namely religious queers, African queers, and trans queers.

\subsection{Religious Queers}

Religious queer people have traditionally been seen as 'unusual' queers. EuroAmerican theories have historically positioned religion and sexuality as irreconcilably contradictory. However, religious scholars and theologians have argued that this narrative is limited within African and other postcolonial contexts. Scholars have therefore committed to nuancing this narrative by demonstrating the ways in which queer religious people are able to navigate these two seemingly incongruent identities, by resisting, transforming and inhabiting religious and cultural norms (Puar 2007; van Klinken \& Gunda 2012; van Klinken 2015; 2019; West et al. 2016). 
Tanya Zion-Waldocks' (2015) case study of Israeli Modern-Orthodox Agunah activists, maps out an activism which she terms 'devoted resistance'. She explores how the women in her study are able to advocate for women's rights and critique particular gendered beliefs and traditions precisely because they are 'devoutly devoted' to them (Zion-Waldocks 2015: 73). This concept of devoted resistance communicates what scholars working at the intersection of religion and sexuality have theorised. In the work of Jaspir Puar (2007) on queer Muslims and Nathanael Homewood's (2016) and Adriaan van Klinken's $(2015 ; 2019)$ respective works on queer Christians in Africa, they critique Western and Eurocentric understandings of agency as located in resistance to norms by demonstrating the ways in which religious queers enact agency not only through resisting, but also through inhabiting and reinforcing dominant religious norms. These expressions of agency resonate with Saba Mahmood's (2006) argument that agency can be expressed in behaviour that reproduces dominant norms. This is because agency can be understood not only as resistance but as 'lived and inhabited, aspired to, reached for, and consummated' (Mahmood 2006: 192).

This may seem to counter to what Western queer theorists have imagined as subversive and disruptive to norms. However, this traditional queer frame pays little attention to the economic and social contexts that shape 'compliance'. Further, it fails to account for why certain normative ways of being are enacted and at times even protected by those who are seemingly excluded from those norms. A decolonial queer politics, on the other hand, disrupts the notion that we can proceed from an already determined understanding of what agency is. Mahmood (2006) argues that, instead, we should discover and analyse different 'modalities of agency' through the multiple ways people inhabit norms.

\subsection{African Queers}

In a globally politicised context where public declarations of 'coming out' and fighting legal battles has become emblematic of what is considered queer activism, acts of silence and discretion are easily construed as unusual acts of passivity or complicity. This neglects to account for what Adriaan van Klinken (2015: 954) has identified as an African resistance to Western forms of activism by refusing to speak out. By drawing on the work of Marc Epprecht (2004: 37), van Klinken (2015: 954) acknowledges that the proliferation of 
Western forms of activism has placed a strain on, what he argues, is a precolonial African 'culture of discretion' which allowed a permissibility around homosexuality precisely because of the silence surrounding it. He argues that the globalisation and politicisation of queer identities puts pressure on sexual minorities in Africa to 'speak out' which, instead of fostering the type of protest and Pride activism common in the Western and European context, rather repositions them as marginal to resistance and sometimes frames them as passive and complicit agents of heteronormativity (van Klinken 2015: 954). Power and privilege therefore intersects with and constitutes the ways in which activism can be performed. While black queer people have often been at the frontline of movements such as Black Lives Matter and \#RhodesMustFall, black queer activism that falls outside of Western forms of activism has been less acknowledged. An indecent queer activism thus means accounting for what Nthabiseng Motsemme (2004: 910f) calls 'economies of invisibility'.

'Economies of invisibility' denotes the power implicated in various silences. Some silences, such as that of affluent white gay people, may indeed be interpreted as apathy. In an interview between Oswin and a staff member of the Equality Project, the non-profit organisation that took over from the NCGLE, they said, 'We went from a situation where being homosexual was a schedule 1 offence to being in the constitution and having sodomy scrapped. And now it doesn't matter to people. They have pension funds, we have immigrations laws...Most gay people, if they live in Sandton or Rosebank or Cavendish, think, what's the problem? So they don't give back' (Oswin 2007: 662). However, in Motsemme's study of women's depositions in the Truth and Reconciliation Commission, she found that women's silences were often an enactment of agency in inhibited conditions. Therefore, accounting for the economies of invisibility requires consideration for the likelihood and possibilities of 'exposure, scrutiny, and surveillance' (Baderoon 2015: 900).

In queer research, Eve Kosofsky Sedgwick (1990: 3) in her influential work 'The Epistemology of the Closet' argues that there is a false binary which exists between 'what one says and what one does not say'. Acts of coming out or speaking out, however, reify that binary with speaking being deemed active while silence is rendered passive (cf. Francis \& Reygan 2016). In challenging this binary, Sedgwick (1990: 3) argues that silence is indeed a 'speech act' which has been incorrectly rendered marginal because it has been affiliated with being in the closet and thus equated to betraying or concealing 
a more authentic identity. Butler (1993: 309) also questions this assumption when she asks, 'What is it that is 'out', made manifest and fully disclosed, when and if I reveal myself as a lesbian? What is it that is now known, anything?' I am unconvinced that the act of coming out and speaking out are intimately linked, or that public resistance is somehow more transgressive and subversive than silence. Under an indecent queer activism, silence could be interpreted as an agentive act which pushes back against colonial narratives often driven by those with access to more power and with less to lose.

\subsection{Trans Queers}

An indecent activism should acknowledge the ways in which bodies and sex are integral to queer activism, especially those bodies that disrupt heteronormative agendas. Tamara Shefer (2019) demonstrates the ways in which trans bodies have continually been left out of activist struggles, including those operating with a decolonial agenda, such as the fallist student movements. Shefer explores the performative activism of the Trans collective, an offshoot of the larger \#RhodesMustFall movement. She describes the embodied performance as follows:

The group performed a piece of guerrilla theatre when they disrupted the opening of a photo exhibition held at the University of Cape Town (UCT, where the \#RMF [\#RhodesMustFall] movement started in 2015) to commemorate a year of decolonial student activism. The group protested by lying in front of the entrance to the exhibition, with text inscribed on their partially dressed bodies, and matching red painted text over some of the exhibited photographs (Shefer 2019: 424).

Shefer argues that the presence of non-conforming bodies and semi-nudity challenged various intersectional norms which continue to position these bodies as failing to matter (in a Butlerian sense).

While the body is an important site of individual identity construction and deconstruction, it is also complexly related to the social (McGuire 1990: 284). As Constance Furey (2012: 7) states, 'The body is never merely blood, flesh and bones, but [the] physical body is intrinsic to the social body, how it is imagined, structured and negotiated socially'. Thus, how bodies are 
produced, policed and inhabited speaks to society's gender and sex ideologies. The body imagined by civilised gay politics is one which is modest, neat and tidy and appropriately gendered. Anything outside of those boundaries is policed and silenced.

The way bodies are viewed, what we do with our bodies, and who has the power to decide both, are intensely political. In fact, in terms of the contemporary struggle to leave behind entrenched patterns of domination and violence, they are key political issues. I want to argue that in order to develop a queer decolonial indecent activism, the visceral visibility of trans bodies in queer activism should be acknowledged.

\section{Conclusion}

This paper contributes theoretically to queer and decolonial understandings of queer agencies and activisms against the backdrop of the moral panic created in apartheid around white homosexuality. Gay politics in post-apartheid South Africa has been restricted as it has continued to work within the frames of morality and civility which apartheid ideologies of race and gender had constructed. Gay politics in South Africa has therefore largely failed to address the norms of Whiteness, patriarchy, and heteronormativity in its activism. It is these norms which have not only privileged a particular version of gay politics but have dismissed other modalities of agency and activism. I therefore argue that a decolonial queer analytic should be applied to the lives of otherwise marginalised queer people in order to begin to theorise an indecent queer activism.

By looking at the ways in which agency is framed in the lives of religious, African and trans queers, I have argued that various modalities of agency which have thus far been marginalised should form part of indecent queer activism. I have by no means been exhaustive in the modalities I have explored, but this paper has sought to expand the conversation around decolonial queer agency in relation to more narrowly defined gay rights activism and agency that has received legitimation. Exploring these various agencies and activisms, illustrates the need for queer activism to include multiple sites of resistance in intersectional ways. In theorising devoted resistance of religious queers, the silence of African queers and the embodied performativities of trans people, hegemonic understandings of activism are challenged. Decolonial queer scholars should thus theorise the power 
implicated in various forms of agency and how these may challenge universal understandings of queer activism. At the same time, by exploring the effects and experiences of various agencies, scholarship can lend a validity to activities and discourses which may in colonial narratives be conceptualised as passive, complicit, silent and crude. In this way, this indecent scholarship in itself serves as a form of academic-activism as it challenges colonial hegemonic narratives of queer agencies, queer lives and queer activisms.

Acknowledgements: This work is based on research supported by the National Research Foundation of South Africa under the auspices of the Desmond Tutu Chair in Religion and Social Justice [Grant Number: 118854].

\section{References}

Althaus-Reid, M. 1999. On Wearing Skirts without Underwear: Indecent Theology Challenging the Liberation Theology of the Pueblo. Poor Women Contesting Christ. Feminist Theology 7, 20: 39 - 51. https://doi.org/10.1177/096673509900702004

Althaus-Reid, M. 2000. Indecent Theology: Theological Perversions in Sex, Gender and Politics. London \& New York: Routledge.

Baderoon, G. 2015. 'I Compose Myself': Lesbian Muslim Autobiographies and the Craft of Self-writing in South Africa. Journal of the American Academy of Religion 83, 4: 897 - 915.

https://doi.org/10.1093/jaarel/lfv075

Butler, J. 1993. Imitation and Gender Insubordination. In Abelove, H., M.A. Barale \& D.M. Halperin (eds.): The Lesbian and Gay Studies Reader. New York: Routledge.

Butler, J. 2004. Undoing Gender. New York: Routledge.

Carolin, A. 2017. Apartheid's Immorality Act and the Fiction of Heteronormative Whiteness. Tydskrif vir Letterkunde 54, 1: 111 - 128. https://doi.org/10.17159/tvl.v.54i1.7

Croucher, S. 2002. South Africa's Democratisation and the Politics of Gay Liberation. Journal of Southern African Studies 28, 2: 315 - 330.

Davids, N. \& Z. Matebeni 2017. Queer Politics and Intersectionality in South Africa. Safundi 18, 2: 161-167.

https://doi.org/10.1080/17533171.2016.1270015

Ditsie, B. \& N. Newman 2002. Simon and I. Available at: 
https://www.youtube.com/watch?v=Cj56iZNVZ-c

Du Pisani, K. 2012. Shifting Sexual Morality? Changing Views on Homosexuality in Afrikaner Society during the 1960s. Historia 57, 2: 182 $-221$.

Duggan, L. 2003. The Twilight of Equality? Neoliberalism, Cultural Politics, and the Attack on Democracy. Boston: Beacon.

Epprecht, M. 2004. Hungochani: The History of a Dissident Sexuality in Southern Africa. Montreal: McGill-Queen's University Press.

Epprecht, M. 2008. Heterosexual Africa? The History of an Idea from the Age of Exploration to the Age of AIDS. Athens: Ohio University Press.

Falkof, N. 2019. Sex and the Devil: Homosexuality, Satanism, and Moral Panic in Late Apartheid South Africa. Men and Masculinities 22, 2: 271 - 293. https://doi.org/10.1177/1097184X18774097

Francis, D. \& F. Reygan 2016. Relationships, Intimacy and Desire in the Lives of Lesbian, Gay and Bisexual Youth in South Africa. South African Review of Sociology 47, 3: 65 - 84.

https://doi.org/10.1080/21528586.2016.1163290

Furey, C. 2012. Body, Society, and Subjectivity in Religious Studies. Journal of the American Academy of Religion 80, 1: 7 - 33.

https://doi.org/10.1093/jaarel/lfr088

Gala. 2019. Till the Time of Trial: The Prison Letters of Simon Nkoli. Available at:

https:/gala.co.za/wp-content/uploads/2019/12/Till-the-time-of-trial2007-nkoli.pdf

Gevisser, M. 1995. A different Fight for Freedom: A History of South African Lesbian and Gay Organisation from the 1950s to the 1990s. In Gevisser, M. \& E. Cameron (eds.): Defiant Desire: Gay and Lesbian Lives in South Africa. New York \& London: Routledge.

Gunda, M. 2017. Silent no Longer! Narratives of Engagement between LGBTI Groups and the Churches in Southern Africa.

Available at:

https://theotherfoundation.org/wp-content/uploads/2017/01/Silent-NoLonger.pdf

Harvey, J. 2015. Disrupting the Normal: Queer Family Life as Sacred Work. I: Talvacchia, K., M. Pettinger \& M. Larrimore (eds.): Queer Christianities: Lived Religion in Transgressive Forms. New York: New York University Press. 
Hoad, N. 1999. Between the White Man's Burden and the White Man's Disease: Tracking Lesbian and Gay Human Rights in Southern Africa. GLQ 5, 4: 559 - 584.

https://doi.org/10.1215/10642684-5-4-559

Hoad, N., L. Martin \& G. Reid 2005. Sex and Politics in South Africa. Cape Town: Double Storey Books.

Homewood, N. 2016. 'I was on fire': The Challenge of Counter-intimacies within Zimbabwean Christianity. In van Klinken, A. \& E. Chitando (eds.): Public Religion and the Politics of Homosexuality in Africa. London \& New York: Routledge.

HSRC \& The Other Foundation. 2015. Progressive Prudes: A Survey of Attitudes towards Homosexuality and Gender Non-conformity in South Africa. Available at:

https://theotherfoundation.org/wpcontent/uploads/2016/09/ProgPrudes_Report_d5.pdf

(Accessed on 11 November 2019.)

Isaack, W. 2003. Equal in Word of Law: The Rights of Lesbian and Gay People in South Africa. Human Rights 30, 3: 19 - 22.

Lake, N. 2014. Black Lesbian Bodies: Reflections on a Queer South African Archive Africa. Insight 44, 1: 69 - 83.

Livermon, X. 2012. Queer(y)ing Freedom: Black Queer Visibilities in Postapartheid South Africa. GLQ: A Journal of Lesbian and Gay Studies 18, 2-3: 297 - 323.

Mahmood, S. 2006. Agency, Performativity, and the Feminist Subject. In Armour, E.T. \& S.M. St. Ville (eds.): Bodily Citations: Religion and Judith Butler. New York: Columbia University Press.

Martens, J. 2007. Citizenship, 'Civilisation' and the Creation of South Africa's Immorality Act, 1927. South African Historical Journal 59, 1: 223 - 241. https://doi.org/10.1080/02582470709464779

Matebeni, Z., S. Monro \& V. Reddy 2018. Queer in Africa: LGBTQI Identities, Citizenship, and Activism. Oxon \& New York: Routledge University Press.

McGuire, M. 1990. Religion and the Body: Rematerializing the Human Body in the Social Sciences of Religion. Journal for the Scientific Study of Religion 29, 3: 283 - 296.

https://doi.org/10.2307/1386459

Motsemme, N. 2004. The Mute Always Speak: On Women's Silences at the 
Truth and Reconciliation Commission. Current Sociology 52, 5: 909 932.

https://doi.org/10.1177/0011392104045377

Nyanzi, S. 2013. Dismantling Reified African Culture through Localised Homosexualities in Uganda. Culture, Health \& Sexuality 15, 8: 952 - 967. https://doi.org/10.1080/13691058.2013.798684

Oswin, N. 2007. Producing Homonormativity in Neoliberal South Africa: Recognition, Redistribution and the Equality Project. Signs 32, 3: 649 669.

Puar, J. 2007. Terrorist Assemblages: Homonationalism in Queer Times. Durham \& London: Duke University Press.

Queen, C. 2008. Never a Bridesmaid, Never a Bride. In Bernstein Sycamore, M. (ed.): That's Revolting! Queer Strategies for Resisting Assimilation. New York: Soft Skull Press.

Ratele, K. 2009. Sexuality as Constitutive of Whiteness in South Africa. NORA - Nordic Journal of Feminist and Gender Research 17, 3: 158-174.

Available at:

https://doi.org/10.1080/08038740903123784

Retief, G. 1995. Keeping Sodom out of the Laager: The Policing of Sexual Minorities in South Africa. In Gevisser, M. \& E. Cameron (eds.): Defiant Desire: Gay and Lesbian Lives in South Africa. New York \& London: Routledge.

Sedgwick, E. 1990. Epistemology of the Closet. Berkeley: University of California Press.

Shefer, T. 2019. Activist Performance and Performative Activism towards Intersectional Gender and Sexual Justice in Contemporary South Africa. International Sociology 34, 4: 418 - 434.

https://doi.org/10.1177/0268580919851430

Sistig, J. \& S. Nadar 2011. Who's in Charge in a Genderless Marriage? A Feminist Queer Analysis of Opposition to Same-sex Marriage by the Marriage Alliance of South Africa. Journal of Gender and Religion in Africa 17, 2: 77 - 92.

Sistig, J. 2011. Who's in Charge in a Genderless Marriage? A Queer Analysis of the Opposition to Same-sex Marriage as Articulated by the Marriage Alliance of South Africa. Awarded at, University of KwaZulu-Natal, Durban. Available at:

https://researchspace.ukzn.ac.za/handle/10413/619 
Stoler, A. 1995. Race and Education of Desire: Foucault's History of Sexuality and the Colonial Order of Things. Durham \& London: Duke University Press.

Thoreson, R. 2008. Somewhere over the Rainbow Nation: Gay, Lesbian and Bisexual Activism in South Africa. Journal of Southern African Studies 34, 3: 679 - 697 .

https://doi.org/10.1080/03057070802259969

van Klinken, A. 2015. Queer Love in a 'Christian Nation': Zambian Gay Men Negotiating Sexual and Religious Identities. Journal of the American Academy of Religion 83, 4: 947 - 964.

https://doi.org/10.1093/jaarel/lfv073

van Klinken A. 2019. Kenyan, Christian, Queer: Religion, LGBT Activism, and the Arts of Resistance in Africa. Pennsylvania: The Pennsylvania State University Press.

van Klinken, A. \& M. Gunda 2012. Taking up the Cudgels against Gay Rights? Trends and Trajectories in African Christian Theologies on Homosexuality. Journal of Homosexuality 59, 1: 114 - 138.

https://doi.org/10.1080/00918369.2012.638549

Vincent, L. \& S. Howell 2014. 'Unnatural', 'Un-African' and 'Ungodly': Homophobic Discourse in Democratic South Africa. Sexualities 17, 4: $472-483$.

https://doi.org/10.1177/1363460714524766

Weber, S. 2015. Daring to Marry: Marriage Equality Activism after Proposition 8 as Challenge to the Assimilationist/ Radical Binary in Queer Studies. Journal of Homosexuality 62, 9: 1147-1173.

https://doi.org/10.1080/00918369.2015.1037127

West, G. 2018. Queering the 'Church and AIDS' Curriculum: Tracing an Improper (and Indecent) Trajectory. Journal of Feminist Studies in Religion 34, 1: 125 - 130.

West, G., C. van der Walt \& K.J. Kaoma 2016. When Faith does Violence: Reimagining Engagement between Churches and LGBTI Groups on Homophobia in Africa. HTS Theological Studies 72, 1: 1 - 8.

https://doi.org/10.4102/hts.v72i1.3511

Zion-Waldocks, T. 2015. Agency, Feminism, and Religion among Orthodox Agunah Activists in Israel. Gender \& Society 29, 1: 73 - 97.

Available at:

https://doi.org/10.1177/0891243214549353 
Megan Robertson

Megan Robertson

Postdoctoral researcher/ Associate Lecturer Desmond Tutu Centre for Religion and Social Justice University of the Western Cape Bellville mrobertson@uwc.ac.za 